\title{
Offshoring of Services in Spain: International Fragmentation of Activities or Change in Procurement Sources?
}

\author{
BEgOÑA FUSTER GARCÍA a ${ }^{\text {, CARMEN MARTÍNEZ MORA a }}$ \\ a Universidad de Alicante, Facultad CC.EE., Campus San Vicente del Raspeig, 03080 Alicante, \\ España.E-mail: bfuster@ua.es, cmmora@ua.es
}

\begin{abstract}
This paper studies the offshoring of services and whether this phenomenon is linked to the international fragmentation of activities or to a shift in outsourcing to foreign rather than domestic suppliers. Analysis is performed using the National Accounting input-output tables of Spain's National Institute for Statistics for the 2000-2007 period. The major findings reveal growth in the offshoring of intermediate services to foreign countries by service providers and manufacturing companies, with greater prevalence among the former. In manufacturing sectors, the analysis indicates that domestic suppliers are being replaced by their foreign counterparts. However, in service sectors these processes correspond mainly to the international fragmentation of activities.
\end{abstract}

Keywords: Offshoring of Services, Input-Output, Manufacturing Sectors, Service Sectors, Spain.

\section{Offshoring de Servicios en España: ¿Fragmentación internacional de actividades o cambio en las fuentes de aprovisionamiento?}

\begin{abstract}
RESUMEN
Este trabajo estudia el offshoring de servicios, diferenciando si está asociado a procesos de fragmentación internacional de las actividades o a un cambio de proveedores nacionales por extranjeros. El análisis se realiza a partir de las tablas input output de la Contabilidad Nacional de España del INE para el periodo 2000-2007.Los principales resultados revelan una creciente deslocalización de servicios intermedios a países extranjeros, tanto por parte de empresas de servicios como de manufacturas, siendo el crecimiento más acentuado en las primeras. En los sectores manufactureros, el análisis revela un proceso de sustitución de proveedores nacionales por extranjeros, mientras que en las ramas de servicios puede afirmarse que se trata fundamentalmente de procesos de fragmentación internacional de actividades.
\end{abstract}

Palabras clave: Offshoring de servicios, input-output, sectores manufactureros, sectores de servicios, España.

Clasificación JEL: F10, F14, L60, L80

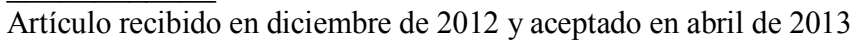

Artículo disponible en versión electrónica en la página www.revista-eea.net, ref. ə-31201 


\section{INTRODUCTION}

One of the characteristic features of international trade in recent years is the major increase in the trade of intermediate inputs, both components and services. This practice has been driven by companies that transfer certain stages of their production processes to other countries, in search of the best geographical location for the different stages of the production process in order to lower costs or increase productive efficiency and thereby improve competitiveness. This strategy, through which national companies procure inputs from abroad, is known in the economic literature as offshoring. The procurement of intermediate inputs from international markets can be carried out within the company itself through foreign direct investment, in other words, from its subsidiaries located in other countries, or through external suppliers located abroad, by means of inter-company agreements. In turn, offshoring, be it internal or external to the company, can encompass the procurement of intermediate or finished products, or specific tasks, in other words, services. This implies substantial changes in the way in which production is organised beyond national borders.

For years, the practice of offshoring has been chiefly associated with outsourcing in industry. In order to cope with growing competition from countries which offer major advantages in terms of costs, manufacturing companies have opted in many cases for strategies based on the outsourcing of certain stages in their chain of production, in particular material inputs, to countries with low labour costs, with a view to reducing costs and improving their competitiveness.

However, given that companies are increasingly opting to procure from other countries not only material inputs but also services that were previously provided within the company itself or contracted out to domestic suppliers, in recent years the phenomenon of offshoring has increasingly spread to different areas of the services sector. On the one hand, industry, which has the most experience in the international arena, is expanding the practice of offshoring not only of intermediate goods but also of services or tasks. This is not just occurring within the company itself through its subsidiaries, but also beyond. On the other hand, as the services sector is experiencing growing expansion in economies throughout the world, the offshoring of services is also becoming increasingly significant.

However, it is very difficult to detect all these phenomena accurately based on the statistical information available. The data for foreign direct investment (FDI) flows can offer information about the importance of outsourcing processes. In principle, these processes should boost the flow of input imports from countries in which outsourcing has taken place. However, this event cannot be detected using statistics for international trade, since they do not reflect the final destination of imports, much less their causes. The alternative sources used in empirical studies at an international level include input-output tables. This study 
uses the input-output tables from Spain's National Institute for Statistics (INE) for the 2000-2007 period.

The aim of this paper is to analyse the offshoring of services in Spain. For this purpose, we examine the extent to which Spanish companies are adopting strategies that foster the international fragmentation of service production, by outsourcing the provision of intermediate services, which were previously internalised within companies themselves, to other countries. To this end, the offshoring index, defined as the proportion of imported intermediate services in comparison to the value of production, is broken down into two components: the first component measures the penetration of imported inputs, and the other represents the total number of intermediate services used in production. Hence, analysis of all the indicators will reveal whether the growing practice of offshoring services corresponds to the international fragmentation of production itself or whether it results from a preference for foreign over domestic suppliers. In a sector-by-sector analysis, this study examines the branches of the manufacturing and service sectors that engage most intensely in this activity, indicating whether it is associated with the international fragmentation of activities or with a change in procurement sources. Furthermore, the analysis of the offshoring of tertiary activity services considers whether this is derived from a greater dependence on intra-sector inputs imported from within the same sector of activity or whether it responds to the use of inter-industrial inputs from other activities.

The paper is structured as follows. Section 2 defines the concept of services offshoring. Section 3 describes the empirical evidence available on services offshoring at an international level and chiefly for the Spanish economy. Section 4 describes the methodology used to measure services offshoring in Spain, as well as the breakdown of the index into its two components. Section 5 examines the phenomenon of services offshoring for the Spanish economy as a whole, both for manufacturing companies and service providers, as well as the sectors that head the international outsourcing of service activities abroad. Finally, the last section sets out the main conclusions drawn.

\section{CONCEPT, CAUSES AND THE EFFECTS OF SERVICES OFFSHORING}

One term offshoring has been used with different meanings in the economic literature. There is no unanimously-held definition. Some studies use the term to refer solely to intra-company imports of inputs, classing inter-company imports as international outsourcing. In other cases, this phenomenon is referred to in a broader sense and deemed to encompass both intra and inter-company imports of inputs. This study uses the definition of Olsen (2006) and, therefore, assumes 
that offshoring exists when companies transfer parts of their production processes to other countries both within the company and externally.

The different business strategies underlying this phenomenon can be divided into two, depending on whether companies procure inputs abroad from independent providers or whether they retain ownership of the production stages they have moved offshore. Accordingly, Olsen (2006) differentiates between offshoring outsourcing (foreign provision that is external to the company) and offshoring insourcing (foreign provision sourced within the company). The term outsourcing on the other hand refers to provision that is external to the company but which could be supplied within the same country (domestic outsourcing) or from abroad (international outsourcing) which in this latter case coincides with offshoring outsourcing.

The term offshoring is associated in some studies with the international fragmentation of production. However, on the basis of the definition given, not all offshoring processes would correspond to this term. This paper assumes that offshoring practices are similar to the international fragmentation of production when certain stages of the production process previously internalised within companies are transferred abroad, but not when it entails substituting domestic suppliers, with which the companies were already practising outsourcing, with foreign suppliers.

The offshoring of intermediate material goods has been widely studied in the empirical literature. However, in recent years this phenomenon has spread significantly to services in both manufacturing companies and the services sector. Due to the novelty of this practice in services, it has not been analysed to the same extent (Blinder, 2006). Muñoz (2007a), in accordance with some researches carried out, studies the magnitude of the phenomenon globally and shows that offshoring of services is still limited but with great potential for growth. Needless to say, not all services are equally susceptible to this practice. In theory, services that can be most easily transferred to other countries are those that do not require personal interaction or services that can be codified (Metters, 2007).

The expansion of offshoring in services can be explained by the growing importance of the services sector in the global economy and, also by a series of other factors which include: advances in new information and communication technologies (ICT), which particularly explains the offshoring of services as this is the main user-sector of ICT; rising competitive pressure faced by companies to reduce costs and increase competitiveness and the progressive commercial liberalisation which has taken place in international markets.

Existing research into the services offshoring encompasses different concepts. Usually, the offshoring of services refers to intermediate service inputs which the services sector itself offshores to foreign countries. However, services 
offshoring has also been analysed for industry and specifically refers to the inputs of services that manufacturing firms contract out internationally. In this case, a distinction is drawn between intermediate inputs of material goods on the one hand and services on the other. Finally, other studies define the services offshoring as the total intermediate service inputs outsourced to foreign countries by an economy. In this latter case, all services contracted out abroad are considered, both by the manufacturing and services sector, as well as all other sectors.

Theoretical analysis of offshoring is recent. Traditional models of international trade explain the flows of end goods between industries and countries, but not the intercompany flows of intermediate products and tasks, which is the consequence of offshoring. Theoretically, the idea of offshoring distorts the traditional concept of specialisation concentrated in one geographical area. The first theoretical references to offshoring can be found in Grossman and RossiHansberg (2006), Blinder (2006) and Olsen (2006). Grossman and Rossi-Hansberg (2006) develop the traditional models of international trade found in Ricardo and Hercher-Ohlin, incorporating the possibility of contracting some of the inputs required for the production process out to foreign countries, when the costs of outsourcing are lower than domestic costs would be. The results show gains derived from international trade when work or tasks are transferred by companies to other countries. This is explained by the reduction in cost of activities contracted out to more cost-efficient locations and the reinforcement and expansion of the activity which companies maintain in the country of origin, which should generate greater efficiency and profitability for investments (Myro and Labrador, 2008).

The empirical literature which analyses the effects of offshoring and, in particular services offshoring, on the economy, focuses chiefly on studying the impact on employment and productivity levels within the companies which engage in this practice (Feenstra and Hanson, 1996, 1999; Raa and Wolf, 2001; Egger and Egger, 2001; Mann, 2003; Bhagwaty et al. 2004; Desai et al. 2005; Amitti and Wei, 2006, 2009; Hijzen et al. 2007; Görg et al. 2008; Winkler, 2010; and Bernhard and Rycx, 2012).

International empirical evidence regarding the effects on employment are not conclusive; rather, they appear to depend on the existing rigidity in the job market, the types of companies and sectors that engage in this practice, as well as the type of offshoring. The effect is not as marked for middle and high technology sectors or when offshoring is inter-sector. When a negative impact is observed, it is only minor. Furthermore, various studies analyse the effect on productivity, showing a positive impact in this case. This is explained by the fact that when company activities are offshored, these tasks are usually the least qualified and lowest yield activities, which increases the proportion of more 
qualified employment in the company. Moreover, the favourable effects on productivity have also been shown to be greater in service companies than manufacturing firms (Olsen, 2006).

For the Spanish economy, there is empirical evidence related to the effects of materials offshoring (Myro and Fernández-Otheo, 2008; Cadarso et al. 2008, 2012; Díaz-Mora et al. 2007; Fariñas and Martín, 2009) and also, although to a lesser degree, of services offshoring (Camacho and Rodríguez, 2008; López Santiago et al. 2011).

\section{EMPIRICAL EVIDENCE}

The empirical evidence for the Spanish economy about offshoring is not very broad and chiefly refers to the procurement of material inputs by the manufacturing sector from abroad, with few studies analysing the provision of services from abroad.

The studies that exclusively analyse the offshoring of intermediate material inputs in Spanish industry include the research conducted by Minondo and Rubert (2001), Gómez et al. (2006) and Cardaso et al. (2007), who use inputoutput tables and take as a reference the offshoring measure proposed originally by Feenstra and Hanson (1996), the participation of intermediate material inputs imported in the total material input procurement (national and imported). Díaz Mora and Gandoy $(2005,2008)$ use the Industrial Business Survey and Díaz Mora et al. (2007) use Industrial Business Survey and input-output tables, taking as an offshoring index the importance of imported intermediate inputs in the value of production. Finally, Fariñas and Martín (2009) analyse international outsourcing based on a sample of Spanish manufacturing companies from the Spanish Ministry of Industry Survey on Business Strategies (Spanish abbreviation ESEE), using the two former indexes. The above studies report an important growth in the offshoring of materials by Spanish industry, with some of them highlighting a sharper rate of growth in offshoring as of 2000 (Díaz Mora et al. 2007; and Canals, 2006).

Canals (2006) was the first to examine the procurement of intermediate services from foreign markets, in other words, the offshoring of services, focusing in this case on Spanish industry. Specifically, this research studies the offshoring of material inputs and the offshoring of services for Spanish manufacturers separately. Camacho and Rodríguez (2008), in turn, analyse the offshoring of services both for the total economy and for the services sector. Both studies use data from input-output tables, the first from Spain's National Accounting from 2000-2004 and the second from the OECD from 2006, extending the study to a total of 14 countries in the EU, specifically all countries in EU-15 with the exception of Luxembourg. The measure of offshoring used in the two previous studies was the proportion of imported intermediate services in 
the total figure for intermediate services, both national and imported. The findings of Canals (2006) reveal the growing magnitude of services offshoring in Spanish industry which, although it is more dynamic than that of material inputs, is smaller in scope than the latter. Camacho and Rodríguez (2008) show that in Spain the level of offshoring is lower in services than in the economy as a whole, a result that is not, however, confirmed for the other countries analysed, where, in spite of the significant differences that exist between them, this practice is found to be more accentuated in the services sector.

Table 1

Research into offshoring of services within the Spanish economy

\begin{tabular}{|c|c|c|c|c|}
\hline $\begin{array}{l}\text { Scope of } \\
\text { analysis }\end{array}$ & Research & Period & Indicator of Offshoring & Source of information \\
\hline $\begin{array}{l}\text { Industry sector: } \\
\text { Offshoring for } \\
\text { material inputs } \\
\text { and services }\end{array}$ & $\begin{array}{l}\text { Canals } \\
(2006)\end{array}$ & $2000-2004$ & $\begin{array}{l}\text { The coefficient between imported } \\
\text { intermediate inputs (goods and non- } \\
\text { energy services) by each industry and } \\
\text { the total intermediate inputs (goods and } \\
\text { non-energy services) used by each } \\
\text { industry. }\end{array}$ & Input-output tables \\
\hline \multirow{3}{*}{$\begin{array}{l}\text { Services sector: } \\
\text { Offshoring for } \\
\text { intermediate } \\
\text { services inputs }\end{array}$} & $\begin{array}{l}\text { Camacho } \\
\text { and } \\
\text { Rodríguez } \\
(2008)\end{array}$ & 2006 & $\begin{array}{l}\text { The percentage represented by } \\
\text { intermediate inputs of services imported } \\
\text { by the services sector in the total } \\
\text { intermediate services inputs for the } \\
\text { sector. }\end{array}$ & $\begin{array}{l}\text { Input-output tables from } \\
\text { the OECD (for } 14 \\
\text { countries in the EU) }\end{array}$ \\
\hline & $\begin{array}{l}\text { Muñoz } \\
(2008)\end{array}$ & $1995-2003$ & $\begin{array}{l}\text { Using various indicators to form } \\
\text { hypotheses: } \\
\text { - Imports of business services } \\
\text { - GVA for business services at } \\
\text { constant prices } \\
\text { - Employment in business services } \\
\text { - Investment abroad in business } \\
\text { services } \\
\text { - Imports of business services / total } \\
\text { GVA }\end{array}$ & $\begin{array}{l}\text { Imports (Statistics for } \\
\text { the Foreign Trade of } \\
\text { Services from the } \\
\text { OECD), investments } \\
\text { abroad in business } \\
\text { services (Annual } \\
\text { Foreign Direct } \\
\text { Investment Statistics } \\
\text { from the OECD), } \\
\text { employment and gross } \\
\text { value added (INE } \\
\text { National Accounting) }\end{array}$ \\
\hline & $\begin{array}{l}\text { Ricart and } \\
\text { Rosatti } \\
\text { (2009) }\end{array}$ & $\begin{array}{c}2008 \\
\text { (comparing } \\
\text { the results } \\
\text { obtained } \\
\text { with those } \\
\text { of Ricart } \\
\text { and } \\
\text { Agnese, } \\
2006 \text { ) }\end{array}$ & $\begin{array}{l}\text { In the questionnaire administered to the } \\
\text { company, the variables are: } \\
\text { - They are practising offshoring } \\
\text { - They are not practising offshoring, } \\
\text { but expect to do so. } \\
\text { - They are not practising or even } \\
\text { considering offshoring. }\end{array}$ & $\begin{array}{l}\text { On-line survey of } \\
\text { companies, chiefly } \\
\text { service providers }\end{array}$ \\
\hline
\end{tabular}

Source: Authors' own data.

There are other studies that analyse the offshoring of services in Spain without using the input-output methodology. By verifying partial hypotheses formulated, based on the analysis of certain indicators such as imports, investments abroad in business services, employment and gross value added, Muñoz (2008) concludes that the existence of services offshoring cannot be confirmed 
in the Spanish economy, or that it is of such magnitude that it manifests at a macroeconomic level. In a previous article, Muñoz (2007b) performs services offshoring within the company -establishing new branches in foreign countries. She studies the significance of Spain's disinvestment process in the service sector in the 1993-2004 period. Ricart and Rosatti (2009) base their analysis on an on-line survey of companies and service providers. They compared the results obtained for 2008 with those of 2006 in a previous version of this study (Ricart and Agnese, 2006) and observe a growing trend in the process of services offshoring in Spain, which companies justify as a result of strategic purposes. Another result indicates that companies tend to practice offshoring insourcing when moving knowledge-based activities to other countries, whilst practising offshoring outsourcing for tasks of low added value. Finally, they point to the growing appearance of new destinations in the outsourcing of services. Merino and Rodríguez (2007) analyse the determinants of outsourcing strategies of services activities by manufacturers using Spanish firm's data included in the Survey on Business Strategies (ESEE) of the Spanish Ministry of Industry, but the authors do not distinguish between domestic and international outsourcing.

\section{METHODOLOGY}

The empirical literature which analyses offshoring indexes on the basis of input-output tables chiefly uses two indicators. On the one hand, early research measures offshoring as the proportion of imported intermediate inputs (III) in the total intermediate inputs used, both national and imported (TII), following the methodology initially proposed by Feenstra and Hanson $(1996,1999)$. More recent research on the other hand (Campa and Goldberg, 1997; Geishecker and Görg, 2005; and Ekholm and Hakkala, 2006) uses the proportion of imported intermediate inputs (III) in the value of production (VP) as an indicator of offsho-ring.

Growth in any of these indicators shows an increase in dependence on imported inputs, either in relation to the total inputs consumed or per unit produced. In both cases, these increases might be due to contracting out to foreign rather than national suppliers, which would not be indicative that offshoring practices are associated with the fragmentation of production itself. To analyse whether an increase in the proportion of imported intermediate inputs obeys a change in the source of provision (from national to foreign suppliers), or whether it is the result of a process of fragmentation of production itself, the offshoring indicator, defined as the proportion of imported intermediate inputs in the value of production, can be broken down into two components: on the one hand, the ratio of imported inputs to total inputs used, and on the other hand, the total intermediate inputs used in relation to the value of production. 


$$
\text { OFFSH }_{j t}=\frac{\sum_{i=1}^{n} I I I_{i j t}}{V P_{j t}}=\frac{\sum_{i=1}^{n} I I I_{i j t}}{\sum_{i=1}^{n} T I I_{i j t}} X \frac{\sum_{i=1}^{n} T I I_{i j t}}{V P_{j t}}
$$

Where $\mathrm{OFFSH}_{\mathrm{jt}}$ represents the level of offshoring in sector $\mathrm{j}$ in year $\mathrm{t}$; $\mathrm{III}_{\mathrm{ijt}}$ represents the intermediate inputs imported by sector $\mathrm{j}$ from sector $\mathrm{i}$ in year $\mathrm{t}$; $\mathrm{TII}_{\mathrm{ij}}$ the total inputs used by sector $\mathrm{j}$ from sector $\mathrm{i}$ in year $\mathrm{t}$; and $\mathrm{VP}_{\mathrm{jt}}$ the value of production for sector $\mathrm{j}$ in year $\mathrm{t}$.

For the international fragmentation of production to exist, there would have to be growth in all factors in the equation (1). In this case, there would be increases in the importation of inputs per unit produced (increase in III/VP) because companies are no longer producing certain inputs but rather procuring them from other countries (increase in TII/VP) and, specifically, from suppliers outside the country (increase in III/TII). However, positive evolution in the total indicator that is not associated with increases in the other components would not point to the international fragmentation of production. Hence, increases in the offshoring indicator (III/VP) accompanied by a negative or null variation in the TII/VP factor would be showing that the importation of inputs per unit produced is increasing, but as a result of replacing inputs contracted out nationally for imported ones.

This breakdown of the offshoring index, used by Díaz Mora et al. (2007) to analyse the offshoring of materials in the Spanish economy, and by Castellani et al. (2010) to study the offshoring of both materials and services in Italy, is adopted in this paper. The aim is to analyse offshoring of services associated with the international fragmentation of activities, for the Spanish economy as a whole, as well as for the manufacturing and service sectors. Unlike previous studies that have used the input-output methodology to study the offshoring of services in Spain (Canals, 2006 and Camacho and Rodríguez, 2008), this study identifies offshoring with the ratio of imported intermediate services to the value of production, analysing the three aforementioned indicators together to ascertain whether it corresponds to the international fragmentation of activities or simply to a move towards contracting out to foreign rather than domestic suppliers.

When studying the offshoring of services in tertiary activities, a distinction is drawn between an indicator of broad offshoring (BO) and narrow offshoring (NO), in accordance with Feenstra and Hanson (1996, 1999), who restrict the concept of the international fragmentation of production to the use of intermediate inputs within the same branch of activity. The broad indicator analyses all imported services, both from the sector itself and from other branches of activity, which uses activity $\mathrm{j}$ in year $\mathrm{t}\left(\mathrm{BO}_{\mathrm{jt}}\right)$, whereas the narrow indicator considers imports of intermediate services carried out by activity $\mathrm{j}$ within its own branch of activity $\mathrm{i}$ in year $\mathrm{t}\left(\mathrm{NO}_{\mathrm{jt}}\right)$. 


$$
B O_{j t}=\frac{\sum_{i=1}^{n} I I I_{i j t}}{V P_{j t}} \quad N O_{j t}=\frac{I I I_{j j t}}{V P_{j t}}
$$

Where $\mathrm{III}_{\mathrm{ijt}}$ represents the intermediate inputs imported by sector $\mathrm{j}$ from sector $\mathrm{i}$ in year $\mathrm{t}$; $\mathrm{III}_{\mathrm{jj}}$ the total inputs used by sector $\mathrm{j}$ within the same sector $\mathrm{j}$ in year $\mathrm{t}$; and $\mathrm{VP}_{\mathrm{jt}}$ the value of production in sector $\mathrm{j}$ in year $\mathrm{t}$.

\section{THE OFFSHORING OF SERVICES IN SPAIN}

\subsection{Penetration of imports, outsourcing and offshoring of services}

Firstly, the provision of intermediate service inputs from abroad is analysed in relation to the total inputs of services used, both of national and imported origin, providing an indicator that measures the penetration of imported inputs (III/TII). This points to a growing trend in the period analysed, 2000-2007, both for manufacturing firms and service providers (Table 2), which indicates that both sectors are becoming increasingly dependent on imported intermediate services. A greater dependency is observed on the part of manufacturers, although service providers appear to be more dynamic with regard to this practice. In spite of its growing importance, the external dependence on imported intermediate services is still fairly small in comparison with the importation of intermediate material inputs, as shown in the work of Minondo and Rubert (2001), Canals (2006) and Fariñas and Martín (2009).

This confirms the findings of Canals (2006), who analyses the offshoring of both services and materials for Spanish industry, based on the same ratio, and also observes the growth of services offshoring, which contrasts with moderate evolution in the offshoring of materials. This growth trend could be conditioned by the effect of prices, since the rise of the Euro in the period studied might explain why companies have tended to procure services from other countries.

The penetration levels for imported inputs obtained in this research are slightly lower than those found by Camacho and Rodríguez (2008), who study the offshoring of services based on the 2006 input-output tables from the OECD, based on the modification of the indicator developed by Feenstra and Haanson $(1996,1999)$ carried out by the OECD (De Backer and Yamano, 2007). These authors obtain a higher index of offshoring (9.64\%) than found in this study (8.84\%) for all service branches in Spain in 2006.

Secondly, the proportion of total intermediate inputs of services per unit produced (TII/VP) is calculated, representing the extent of outsourcing. A growth trend is observed throughout the period analysed, which reveals that companies are abandoning activities they had previously carried out (Table 2). In manufacturing firms, unlike the services sector, this indicator falls in 2006 and stabilises in 2007, which shows that manufacturing companies have not increased the number of outsourced activities in recent years. Furthermore, the 
data show that the proportion of service inputs per unit produced is higher in the services sector than in the manufacturing industry.

Finally, the results for the global indicator, in other words, for the proportion of intermediate imported services per unit produced (III/VP), show a significant increase between 2000 and 2007 (Table 2), which reveals that companies are abandoning activities that were once an integral part of their operations.

\section{Table 2}

Offshoring of services, penetration of imported services, and service outsourcing activities

\begin{tabular}{|l|c|c|c|c|c|c|c|c|c|c|}
\hline & $\mathbf{2 0 0 0}$ & $\mathbf{2 0 0 1}$ & $\mathbf{2 0 0 2}$ & $\mathbf{2 0 0 3}$ & $\mathbf{2 0 0 4}$ & $\mathbf{2 0 0 5}$ & $\mathbf{2 0 0 6}$ & $\mathbf{2 0 0 7}$ & $\begin{array}{c}\text { \% Var. } \\
\mathbf{2 0 0 0}-\mathbf{7}\end{array}$ \\
\hline & \multicolumn{7}{|c|}{ Imported intermediate services/total intermediate services (III/TII) } \\
\hline Total Economy & 8.34 & 8.49 & 7.59 & 7.19 & 7.15 & 6.88 & 7.16 & 7.91 & -5.16 \\
\hline Manufacturing and services & 9.19 & 9.44 & 9.34 & 9.03 & 9.03 & 9.06 & 9.63 & 10.32 & 12.29 \\
\hline Manufacturing & 12.37 & 11.70 & 10.14 & 9.16 & 10.64 & 10.46 & 11.89 & 13.10 & 5.90 \\
\hline Services & 7.85 & 8.46 & 9.00 & 8.98 & 8.40 & 8.52 & 8.84 & 9.38 & 19.46 \\
\hline & \multicolumn{7}{|c|}{ Intermediate services /Value of production (TII/VP) } \\
\hline Total Economy & 0.23 & 0.24 & 0.25 & 0.26 & 0.26 & 0.27 & 0.28 & 0.28 & 19.91 \\
\hline Manufacturing and services & 0.23 & 0.23 & 0.24 & 0.24 & 0.25 & 0.25 & 0.25 & 0.26 & 12.73 \\
\hline Manufacturing & 0.18 & 0.19 & 0.20 & 0.20 & 0.20 & 0.21 & 0.20 & 0.20 & 9.50 \\
\hline Services & 0.25 & 0.25 & 0.26 & 0.26 & 0.27 & 0.27 & 0.28 & 0.28 & 11.94 \\
\hline & \multicolumn{7}{|c|}{ Intermediate inputs of imported services / Value of production (III/VP) } \\
\hline Total Economy & 1.92 & 2.02 & 1.94 & 1.89 & 1.88 & 1.87 & 2.00 & 2.18 & 13.72 \\
\hline Manufacturing and services & 2.08 & 2.19 & 2.23 & 2.18 & 2.21 & 2.26 & 2.43 & 2.63 & 26.59 \\
\hline Manufacturing & 2.28 & 2.26 & 2.05 & 1.87 & 2.17 & 2.19 & 2.37 & 2.64 & 15.96 \\
\hline Services & 1.97 & 2.15 & 2.33 & 2.35 & 2.24 & 2.29 & 2.46 & 2.63 & 33.73 \\
\hline
\end{tabular}

Source: Authors' own data based on Spain's National Accounting Input-Output Tables (INE).

Taking into account the results of all the indicators analysed previously, both in the services and manufacturing sectors, there was growth in the offshoring of services between 2000 and 2007. However, whilst in the services sector such practices can be associated with the international fragmentation of activities, in the sense that they correspond to the abandoning of internal activities by the company which are then outsourced to foreign countries, in manufacturing firms, as of 2005, this phenomenon entails the replacement of national suppliers, to which activities had previously been outsourced, with international suppliers. This result for manufacturers coincides with the data published by many companies, showing that in recent years there has been a growing process of activity outsourcing, but preferably to national companies, owing to the greater confidence they create over distant foreign suppliers. However, since the onset of the global economic crisis, there has been a move towards replacing national suppliers with their foreign counterparts who offer lower prices, owing 
to the greater competitive pressures to which they are subject. It has not been possible to verify these facts owing to the lack of data available for the years subsequent to the period examined by the study.

With regard to the magnitude of the phenomenon, it is still fairly small. The indexes for services offshoring (III/VP, Intermediate inputs of imported services/Value of production) reach values of between $2 \%$ and $2.7 \%$ both for the service and manufacturing industries. These are limited percentages compared with those obtained in studies analysing the offshoring of material inputs (Gómez et al. 2006; Díaz Mora et al. 2007; and Cadarso et al. 2007), yet there is a prospect for future growth bearing in mind that the offshoring of materials is already considered a mature process, whereas services offshoring is very recent.

Next, the narrow indicator is analysed to ascertain the extent to which tertiary branches procuring intermediate services from other countries import services from within their own branch of activity. Unlike the broad indicator presented previously, the narrow indicator measures dependence on intra-sector imported inputs. Therefore, tasks that are outsourced to foreign countries but which were previously carried out by a national company within the same sector of activity are estimated (Table 3 ). The growth trend detected in the offshoring of services through the broad indicator (growth of 33.7\% between 2000 and 2007) is accentuated when the narrow indicator is calculated (growth of $42.15 \%)$.

Table 3

Broad offshoring and narrow offshoring

(in percentages)

\begin{tabular}{|l|c|c|c|c|c|c|c|c|c|}
\hline & $\mathbf{2 0 0 0}$ & $\mathbf{2 0 0 1}$ & $\mathbf{2 0 0 2}$ & $\mathbf{2 0 0 3}$ & $\mathbf{2 0 0 4}$ & $\mathbf{2 0 0 5}$ & $\mathbf{2 0 0 6}$ & $\mathbf{2 0 0 7}$ & $\begin{array}{c}\text { \% var. } \\
\mathbf{2 0 0 0}-\mathbf{7}\end{array}$ \\
\hline Broad Offshoring & 1.97 & 2.15 & 2.33 & 2.35 & 2.24 & 2.29 & 2.46 & 2.63 & 33.73 \\
\hline Narrow Offshoring & 0.75 & 0.90 & 0.83 & 0.88 & 0.87 & 0.87 & 0.97 & 1.07 & 42.15 \\
\hline
\end{tabular}

Source: Authors' own data based on Spain's National Accounting Input-Output Tables (INE).

\subsection{Sectorial analysis}

Sectorial analysis for the manufacturing branches reveals that they all engage in the offshoring of services, with the Chemical industry and the Tobacco industry displaying a greater external dependence on imported services in relation to the value of their production (Table 4). Furthermore, a growth trend is observed for this practice in most branches between 2000 and 2007, with the Rubber and plastic materials industry and the Paper industry displaying the highest growth. 
Table 4

Offshoring of services in manufacturing branches

\begin{tabular}{|c|c|c|c|c|}
\hline & $\begin{array}{l}\text { III/VP } \\
2000\end{array}$ & $\begin{array}{l}\text { III/VP } \\
2007\end{array}$ & $\begin{array}{c}\text { Difference in } \\
\text { percentage points }\end{array}$ & $\begin{array}{c}\text { Variation rate } \\
2000-07\end{array}$ \\
\hline Rubber and plastic materials industry & 1.08 & 3.94 & 2.86 & 264.61 \\
\hline Paper industry & 0.52 & 3.09 & 2.57 & 493.44 \\
\hline Electronic material manufacturing & 1.44 & 3.34 & 1.89 & 131.07 \\
\hline Textile industry & 1.35 & 3.24 & 1.88 & 139.27 \\
\hline Manufacturing of other transportation material & 1.59 & 3.34 & 1.75 & 110.17 \\
\hline Ceramics industry & 0.87 & 2.43 & 1.56 & 180.09 \\
\hline $\begin{array}{l}\text { Manufacturing of machinery and electrical and } \\
\text { electronic material }\end{array}$ & 1.47 & 2.91 & 1.44 & 97.72 \\
\hline Manufacturing of metal products & 0.67 & 1.91 & 1.24 & 185.69 \\
\hline Medical-surgical and precision instruments & 0.85 & 2.07 & 1.22 & 143.20 \\
\hline Manufacturing of glass and glass products & 0.42 & 1.62 & 1.20 & 286.26 \\
\hline Clothing industry and fur trade & 1.20 & 2.40 & 1.20 & 99.73 \\
\hline Manufacturing of cement, lime and plaster & 0.37 & 1.29 & 0.92 & 250.60 \\
\hline Timber and cork industry & 0.32 & 1.24 & 0.92 & 287.75 \\
\hline Leather and footwear industry & 2.33 & 3.16 & 0.83 & 35.72 \\
\hline Chemical industry & 5.29 & 5.93 & 0.63 & 11.93 \\
\hline Furniture and other manufacturing industries & 1.91 & 2.49 & 0.58 & 30.33 \\
\hline Metallurgy & 0.58 & 1.15 & 0.57 & 97.84 \\
\hline Manufacturing of other ore products & 1.45 & 1.85 & 0.40 & 27.59 \\
\hline Other food industries & 2.41 & 2.25 & -0.17 & -6.94 \\
\hline Machinery and mechanical equipment & 2.16 & 1.84 & -0.31 & -14.56 \\
\hline Meat industry & 2.33 & 1.89 & -0.45 & -19.26 \\
\hline Publishing and graphic arts & 3.73 & 3.05 & -0.68 & -18.33 \\
\hline Transport material & 3.28 & 2.49 & -0.79 & -24.05 \\
\hline Tobacco industry & 6.09 & 5.18 & -0.91 & -14.95 \\
\hline Dairy industries & 2.54 & 1.59 & -0.95 & -37.40 \\
\hline Beverage making & 3.83 & 2.77 & -1.06 & -27.79 \\
\hline Office machinery and IT equipment & 4.36 & 0.73 & -3.63 & -83.32 \\
\hline
\end{tabular}

Note: Imported intermediate services/total intermediate services (III/TII), Intermediate services Nalue of production (TIINP) and Intermediate inputs of imported services / Value of production (IIIVP).

Branches of activity ordered from highest to lowest variation in the ratio IIIVPP (percentage point difference).

Source: Authors' own data based on Spain's National Accounting Input-Output Tables (INE).

With regard to the offshoring of services by service branches, the activities that display the highest dependence on imported intermediate services per product unit (broad offshoring) are Travel agency activities, Maritime transportation and Air and space transportation, with indices ranging between 17\% and 24\% (Table 5). Further down the scale but also of note are Insurance and pension plans, Market recreational, cultural and sporting activities, Wholesale and intermediary trade, Auxiliary activities, IT activities, Financial brokerage, Postal services and telecommunications and Activities linked to transport, with indices ranging between $5 \%$ and $8 \%$. Most of these activities present higher narrow offshoring indexes, in other words, they display a high level of dependence on intra-sector imported intermediate services, with the exception of Maritime transportation, a branch in which all imported intermediate services are inter-sector. 
Furthermore, the results show that there are two branches of activity that do not offshore services, Non-market public sanitation for public administrations and Homes that employ domestic staff, along with others, such as the Restaurant trade, which presents a negligible level.

As a whole, $41 \%$ of intermediate services imported per product unit are intra-sector. The branches in which the majority (over 50\%) of imported intermediate inputs of services are from the same branch of activity are, in descending order, Activities linked to transport, Other business activities, Auxiliary activities, Market recreational, cultural and sporting activities, Postal services and telecommunications, Financial brokerage, and Insurance and pension plans. It should also be noted that 14 of the 33 service branches display intra-sector external dependence, whereas in the others, external dependency is exclusively inter-sector.

Table 5

Broad offshoring of services, and intra/inter sector dependence, 2007

\begin{tabular}{|c|c|c|c|c|c|}
\hline \multirow[b]{2}{*}{ Branches } & \multirow[b]{2}{*}{ BO } & \multicolumn{2}{|c|}{ Intra-sector } & \multicolumn{2}{|c|}{ Inter-sector } \\
\hline & & Index & $\begin{array}{l}\text { \% of } \\
\text { BO }\end{array}$ & Index & $\begin{array}{l}\text { \% of } \\
\text { BO }\end{array}$ \\
\hline Travel agency activity & 23.70 & 6.45 & 27.20 & 17.25 & 72.80 \\
\hline Maritime transport & 22.15 & 0.00 & 0.00 & 22.15 & 100.00 \\
\hline Air and space transport & 17.38 & 1.62 & 9.30 & 15.76 & 90.70 \\
\hline Insurance and pension plans & 7.69 & 4.23 & 55.04 & 3.46 & 44.96 \\
\hline Market recreational, cultural and sporting activities & 6.95 & 5.61 & 80.65 & 1.35 & 19.35 \\
\hline Wholesale and intermediary trade & 6.60 & 0.39 & 5.91 & 6.21 & 94.09 \\
\hline Auxiliary activities & 6.50 & 5.30 & 81.52 & 1.20 & 18.48 \\
\hline IT activities & 5.16 & 0.27 & 5.14 & 4.90 & 94.86 \\
\hline Financial brokerage & 5.07 & 2.98 & 58.81 & 2.09 & 41.19 \\
\hline Postal service and telecommunications & 4.98 & 3.96 & 79.46 & 1.02 & 20.54 \\
\hline Activities linked to transport & 4.94 & 4.54 & 91.82 & 0.40 & 8.18 \\
\hline Market research and development & 3.07 & 0.00 & 0.00 & 3.07 & 100.00 \\
\hline Other business activities & 2.72 & 2.35 & 86.18 & 0.38 & 13.82 \\
\hline $\begin{array}{l}\text { Non-market associative activities of non-profit } \\
\text { institutions serving households }\end{array}$ & 2.42 & 0.00 & 0.00 & 2.42 & 100.00 \\
\hline Accommodation & 1.97 & 0.00 & 0.00 & 1.97 & 100.00 \\
\hline Rental of domestic machinery and equipment & 1.54 & 0.00 & 0.00 & 1.54 & 100.00 \\
\hline Retail trade, repair of personal effects & 1.31 & 0.00 & 0.00 & 1.31 & 100.00 \\
\hline Railway transport & 1.22 & 0.00 & 0.00 & 1.22 & 100.00 \\
\hline Sale-repair of motor vehicles; trade of automotive fuel & 1.05 & 0.24 & 23.36 & 0.80 & 76.64 \\
\hline Market associative activities & 0.94 & 0.00 & 0.00 & 0.94 & 100.00 \\
\hline Land transport and pipeline transport & 0.94 & 0.00 & 0.02 & 0.94 & 99.98 \\
\hline Public administration & 0.70 & 0.00 & 0.00 & 0.70 & 100.00 \\
\hline Public market sanitation & 0.69 & 0.00 & 0.00 & 0.69 & 100.00 \\
\hline Real estate activities & 0.54 & 0.00 & 0.00 & 0.54 & 100.00 \\
\hline Non-market recreational and cultural activities & 0.40 & 0.00 & 0.00 & 0.40 & 100.00 \\
\hline Market education & 0.18 & 0.00 & 0.00 & 0.18 & 100.00 \\
\hline
\end{tabular}


Table 5 (continue)

Broad offshoring of services, and intra/inter sector dependence, 2007

\begin{tabular}{|l|c|c|c|c|c|}
\hline \multicolumn{1}{|c|}{ Branches } & \multirow{2}{*}{ Bo } & \multicolumn{2}{c|}{ Intra-sector } & \multicolumn{2}{c|}{ Inter-sector } \\
\cline { 3 - 7 } & & Index & $\begin{array}{c}\text { \% of } \\
\text { BO }\end{array}$ & Index & $\begin{array}{c}\text { \% of } \\
\text { BO }\end{array}$ \\
\hline Non-market healthcare and social services & 0.16 & 0.00 & 0.00 & 0.16 & 100.00 \\
\hline Non-market education & 0.11 & 0.00 & 0.00 & 0.11 & 100.00 \\
\hline Various personal services activities & 0.09 & 0.03 & 37.50 & 0.05 & 62.50 \\
\hline Market healthcare and social services & 0.07 & 0.00 & 0.00 & 0.07 & 100.00 \\
\hline Restaurant trade & 0.02 & 0.00 & 0.00 & 0.02 & 100.00 \\
\hline $\begin{array}{l}\text { Non-market public sanitation for Public } \\
\text { Administrations }\end{array}$ & 0.00 & 0.00 & - & 0.00 & - \\
\hline Homes that employ domestic staff & 0.00 & 0.00 & - & 0.00 & - \\
\hline Total service branches & 2.63 & 1.07 & 40.62 & 1.56 & 59.38 \\
\hline
\end{tabular}

Note: The intra-sector indicator represents narrow offshoring and refers to dependence on intermediate services imported from the same branch of activity in relation to the value of production and the inter-industrial indicator refers to dependence on intermediate services from other tertiary branches in relation to the value of production. The sum of these two indicators gives broad offshoring (BO) and measures total dependency on imported intermediate services in relation to the value of production (IIIVP). Branches are ordered from highest to lowest level in terms of the broad offshoring of services.

Source: Authors' own data based on Spain's National Accounting Input-Output Tables (INE).

From a dynamic perspective, the tendency observed between 2000 and 2007 reveal a greater magnitude of offshoring for the services sector as a whole which is explained by a greater dependence on intra-sector imported services. The branches of activity which have registered higher levels of growth in offshoring were Maritime transport, Travel agency activity, Wholesale and intermediary trade, Auxiliary activities, Market research and development, Insurance and pension plans, IT activities, Postal services and telecommunications and Rental of machinery and domestic equipment (Table 6).

\section{Table 6}

Dynamics of broad and restricted offshoring indicators

(Variation in percentage points between 2000 and 2007)

\begin{tabular}{|c|c|c|c|c|c|}
\hline Branches & $\begin{array}{c}\text { BO } \\
2000\end{array}$ & $\begin{array}{c}\text { BO } \\
2007\end{array}$ & $\begin{array}{c}\text { BO } \\
\text { Diff. percent. } \\
\text { points } \\
2000-2007\end{array}$ & $\begin{array}{l}\text { Intra- } \\
\text { sector }\end{array}$ & $\begin{array}{l}\text { Inter- } \\
\text { sector }\end{array}$ \\
\hline Maritime transport & 13.42 & 22.15 & 8.73 & 0.00 & 8.73 \\
\hline Travel agency activities & 16.04 & 23.70 & 7.66 & 5.12 & 2.54 \\
\hline Wholesale and intermediary trade & 1.12 & 6.60 & 5.48 & -0.02 & 5.5 \\
\hline Auxiliary activities & 1.53 & 6.50 & 4.97 & 5.3 & -0.33 \\
\hline Market research and development & 0.65 & 3.07 & 2.42 & 0.00 & 2.42 \\
\hline Insurance and pension plans & 5.28 & 7.69 & 2.41 & 3.99 & -1.58 \\
\hline IT activities & 3.05 & 5.16 & 2.12 & -0.87 & 2.99 \\
\hline Postal services and telecommunications & 3.58 & 4.98 & 1.4 & 1.2 & 0.2 \\
\hline Rental of machinery and domestic equipment & 0.28 & 1.54 & 1.26 & 0.00 & 1.26 \\
\hline
\end{tabular}


Table 6 (continue)

Dynamics of broad and restricted offshoring indicators

(Variation in percentage points between 2000 and 2007)

\begin{tabular}{|c|c|c|c|c|c|}
\hline Branches & $\begin{array}{c}\text { BO } \\
2000\end{array}$ & $\begin{array}{c}\text { BO } \\
2007\end{array}$ & $\begin{array}{c}\text { BO } \\
\text { Diff. percent. } \\
\text { points } \\
2000-2007\end{array}$ & $\begin{array}{l}\text { Intra- } \\
\text { sector }\end{array}$ & $\begin{array}{l}\text { Inter- } \\
\text { sector }\end{array}$ \\
\hline $\begin{array}{l}\text { Non-market associative activities of non-profit } \\
\text { institutions serving households }\end{array}$ & 1.22 & 2.42 & 1.2 & 0.00 & 1.2 \\
\hline Retail trade, repair of personal effects & 0.45 & 1.31 & 0.85 & 0.00 & 0.85 \\
\hline $\begin{array}{l}\text { Sale and repair of motor vehicles; trade of fuel for } \\
\text { automobiles }\end{array}$ & 0.21 & 1.05 & 0.83 & 0.24 & 0.59 \\
\hline Market public sanitation & 0.07 & 0.69 & 0.61 & 0.00 & 0.61 \\
\hline Rail transport & 0.72 & 1.22 & 0.5 & 0.00 & 0.5 \\
\hline Non-market recreational and cultural activities & 0.01 & 0.40 & 0.39 & 0.00 & 0.39 \\
\hline Land transport and pipeline transport & 0.61 & 0.94 & 0.33 & 0.00 & 0.33 \\
\hline Real estate activities & 0.26 & 0.54 & 0.27 & 0.00 & 0.27 \\
\hline Public administration & 0.50 & 0.70 & 0.19 & 0.00 & 0.19 \\
\hline Financial brokerage & 4.95 & 5.07 & 0.12 & 1.58 & -1.46 \\
\hline Market education & 0.08 & 0.18 & 0.09 & 0.00 & 0.09 \\
\hline Non-market education & 0.01 & 0.11 & 0.09 & 0.00 & 0.09 \\
\hline Non-market healthcare and social services & 0.13 & 0.16 & 0.04 & 0.00 & 0.04 \\
\hline $\begin{array}{l}\text { Non-market public sanitation for Public } \\
\text { Administrations }\end{array}$ & 0.00 & 0.00 & 0.00 & 0.00 & 0.00 \\
\hline Homes that employ domestic staff & 0.00 & 0.00 & 0.00 & 0.00 & 0.00 \\
\hline Activities linked with transport & 4.95 & 4.94 & -0.01 & 1.2 & -1.21 \\
\hline Market associative activities & 0.97 & 0.94 & -0.03 & 0.00 & -0.03 \\
\hline Restaurant trade & 0.06 & 0.02 & -0.04 & 0.00 & -0.04 \\
\hline Market healthcare and social services & 0.12 & 0.07 & -0.05 & 0.00 & -0.05 \\
\hline Accommodation & 2.09 & 1.97 & -0.12 & 0.00 & -0.12 \\
\hline Various personal services activities & 0.82 & 0.09 & -0.74 & 0.03 & -0.77 \\
\hline Other business activities & 3.72 & 2.72 & -0.99 & -0.08 & -0.91 \\
\hline Market recreational, cultural and sporting activities & 8.19 & 6.95 & -1.24 & -0.27 & -0.97 \\
\hline Air and space transport & 22.17 & 17.38 & -4.8 & 0.35 & -5.15 \\
\hline
\end{tabular}

Note: Broad offshoring (BO). Sectors ordered from highest to lowest growth in the broad offshoring index between 2000 and 2007(in percentage differences).

Source: Authors' own data based on Spain's National Accounting Input-Output Tables (INE).

The greater dependence on imported services observed in some of these branches (Auxiliary activities, Travel agency activities, Insurance and pension plans and Postal services and telecommunications) is explained by intra-sector inputs, whereas in the other branches, only dependence on inter-sector imported services has increased, which does not affect production or employment in the branch itself but rather that of national suppliers. Financial brokerage and Activities linked to transport are two branches that also present an increasing dependence on intra-sector inputs of services, whilst significantly reducing their dependence on inter-sector inputs. 
Table 7

Breakdown of the III/VP into its components III/TII and TII/VP, 2000 and 2007

\begin{tabular}{|c|c|c|c|c|c|c|}
\hline & \multicolumn{3}{|c|}{ IIIM/TII } & \multicolumn{3}{|c|}{ TIT/VP } \\
\hline & 2000 & 2007 & dif & 2000 & 2007 & dif \\
\hline $\begin{array}{l}\text { Sale and repair of motor vehicles; trade of fuel } \\
\text { for automobiles }\end{array}$ & 0.78 & 3.2 & 2.42 & 26.99 & 32.67 & 5.68 \\
\hline Wholesale and intermediary trade & 3.26 & 17.84 & 14.58 & 34.34 & 37.00 & 2.66 \\
\hline Retail trade, repair of personal items & 1.98 & 4.36 & 2.38 & 23.01 & 29.99 & 6.98 \\
\hline Accommodation & 10.61 & 8.23 & -2.38 & 19.73 & 23.92 & 4.19 \\
\hline Catering & 0.50 & 0.15 & -0.35 & 12.39 & 15.45 & 3.06 \\
\hline Rail transport & 4.28 & 4.11 & -0.17 & 16.92 & 29.70 & 12.78 \\
\hline Land transport and pipeline transport & 1.87 & 2.52 & 0.65 & 32.59 & 37.26 & 4.67 \\
\hline Sea transport & 33.50 & 55.58 & 22.08 & 40.05 & 39.85 & -0.20 \\
\hline Air and space transport & 51.25 & 41.69 & -9.56 & 43.27 & 41.68 & -1.59 \\
\hline Activities linked to transport & 10.52 & 9.07 & -1.45 & 47.04 & 54.44 & 7.41 \\
\hline Travel agency activities & 25.89 & 36 & 10.11 & 61.94 & 65.84 & 3.90 \\
\hline Postal and telecommunication services & 10.68 & 13.39 & 2.71 & 33.54 & 37.23 & 3.69 \\
\hline Financial brokerage & 22.89 & 25.15 & 2.26 & 21.63 & 20.17 & -1.45 \\
\hline Insurance and pension plans & 8.33 & 13.75 & 5.42 & 63.31 & 55.92 & -7.39 \\
\hline Auxiliary activities & 3.29 & 12.93 & 9.64 & 46.61 & 50.28 & 3.66 \\
\hline Real estate activities & 1.05 & 2.47 & 1.42 & 24.69 & 21.70 & -2.99 \\
\hline Rental of machinery and domestic equipment & 0.91 & 4.14 & 3.23 & 30.56 & 37.24 & 6.68 \\
\hline IT activity & 10.29 & 13.14 & 2.85 & 29.62 & 39.30 & 9.68 \\
\hline Market research and development & 3.10 & 11.32 & 8.22 & 21.04 & 27.10 & 6.06 \\
\hline Other business activities & 12.79 & 9.07 & -3.72 & 29.05 & 30.03 & 0.98 \\
\hline Public administration & 3.48 & 3.4 & -0.08 & 14.42 & 20.51 & 6.09 \\
\hline Market education & 0.64 & 1.23 & 0.59 & 12.91 & 14.32 & 1.41 \\
\hline Non-market education & 0.33 & 2.29 & 1.96 & 4.18 & 4.65 & 0.47 \\
\hline Market healthcare and social services & 0.59 & 0.28 & -0.31 & 20.89 & 24.52 & 3.64 \\
\hline $\begin{array}{l}\text { Non-market healthcare and social services for } \\
\text { Public Administrations }\end{array}$ & 0.23 & 0.45 & 0.22 & 14.70 & 14.71 & 0.01 \\
\hline $\begin{array}{l}\text { Non-market healthcare and social services for } \\
\text { NPISHs }\end{array}$ & 2.85 & 3.68 & 0.83 & 30.09 & 29.27 & -0.82 \\
\hline Market public sanitation & 0.38 & 3.82 & 3.44 & 19.29 & 17.98 & -1.31 \\
\hline $\begin{array}{l}\text { Non-market public sanitation for Public } \\
\text { Administrations }\end{array}$ & 0.00 & 0 & 0.00 & 68.46 & 72.58 & 4.12 \\
\hline Market associative activities & 4.03 & 3.78 & -0.25 & 24.00 & 24.91 & 0.91 \\
\hline Non-market associative activities for NPISHs & 3.11 & 6 & 2.89 & 39.12 & 40.24 & 1.12 \\
\hline $\begin{array}{l}\text { Market recreational, cultural and sporting } \\
\text { activities }\end{array}$ & 32.78 & 23.36 & -9.42 & 24.99 & 29.76 & 4.77 \\
\hline $\begin{array}{l}\text { Non-market recreational and cultural activities } \\
\text { for Public Administrations }\end{array}$ & 3.05 & 0.13 & -2.92 & 41.64 & 42.48 & 0.85 \\
\hline $\begin{array}{l}\text { Non-market recreational and cultural activities } \\
\text { for NPISHs }\end{array}$ & 3.93 & 4.37 & 0.44 & 40.44 & 43.56 & 3.13 \\
\hline Diverse personal services & 3.75 & 0.3 & -3.45 & 21.94 & 28.59 & 6.66 \\
\hline
\end{tabular}

Note: Imported intermediate services/total intermediate services (IIITIII), Intermediate services Nalue of production (TIIVP) and Intermediate inputs of imported services / Value of production (IIIVP).

Source: Authors' own data based on Spain's National Accounting Input-Output Tables (INE).

To differentiate between the branches of activity which have registered the 
international fragmentation of activities and those for which offshoring is due to the substitution of domestic suppliers with foreign ones, the disaggregated indicator has been calculated for the different service activities (Table 7).

In the service branches that present the most significant levels of offshoring (III/VP) we can appreciate the international fragmentation of activities except in Maritime transport and Insurance and Pension Plans, in which the process entails contracting out to foreign rather than domestic suppliers.

\section{CONCLUSIONS}

The international fragmentation of production, which involves moving parts of a company's production chain to a foreign country for cost or efficiency purposes, is a strategy that is increasingly used by companies. It implies procuring intermediate inputs from companies based abroad, either through subsidiaries of the company itself or external suppliers. This practice, known in the literature as offshoring, affects material goods as well as tasks or intermediate services.

This paper analyses the offshoring of services in Spain; in other words, the extent to which Spanish manufacturing and service companies are offshoring their intermediate services to other countries. A distinction is made here between whether this external dependence corresponds to the international fragmentation of production itself or whether it involves switching suppliers from domestic to international companies. Aggregated analysis is provided for the Spanish economy as a whole, both for the manufacturing and service sectors, and disaggregated analysis is conducted for the different branches of activity in the 2000-2007 period based on Spain's National Accounting input-output tables.

The results show that between 2000 and 2007 the Spanish economy registered growth in the offshoring of intermediate services to foreign countries, by services and manufacturing companies, with more accentuated growth registered in service providers. Furthermore, a higher rate of growth for this practice is observed when the study is restricted to the importation of services from the same sector or activity. In the case of manufacturing firms, the offshoring of services, although relevant, is smaller in its scope than the offshoring of material goods analysed by other authors in previous studies.

Sector analysis shows that all branches of manufacturing procure service inputs from other countries, although at different rates of intensity, with the Chemical industry and the Tobacco industry proving to be the most dependent on imported intermediate services per product unit. Furthermore, the majority of manufacturing branches have increased their procurement of intermediate services from other countries in relation to the value of their production. This is due to a process whereby domestic suppliers have been replaced by their foreign counterparts, particularly in recent years. 
With regard to the service branches, this study reveals in aggregated terms that they are importing intermediate services from within their same branch of activity (intra-sector) and also from others (inter-sector). The services activities which depend most highly on imported intermediate services in terms of the value of production are Travel agency activities and Maritime transport. Furthermore, there are two sectors which do not offshore services: Non-market public sanitation for public administrations and Homes which employ domestic staff. The branches in which the majority of imports per product unit are intrasector are Activities related to transport, Other business activities, Auxiliary activities, Market recreational, cultural and sporting activities, Postal services and telecommunications, Financial brokerage and Insurance and pension plans. At the other end of the scale, over 40 percent of service branches only import inter-sector intermediate services. In relation to evolution, the imports of services per product unit display a tendency towards growth between 2000 and 2007, largely due to its intra-sectorial nature. The branches that have increased their activity to the greatest extent - Auxiliary activities, Travel agency activities, Insurance and pension plans and Postal services and telecommunications have done so in relation to intra-sector services. The remaining branches Maritime transport, Market research and development, Rental of machinery and domestic equipment and IT activities -have only increased their dependence on inter-sector imported services. Finally, in all service branches with significant offshoring indexes, these processes represent the international fragmentation of activities, except in Maritime transport and Insurance and pension plans.

\section{REFERENCIAS BIBLIOGRÁFICAS}

AMITI, M.; and WEI S.J., (2006). "Services Outsourcing, Production and Employment: Evidence from the US". IMF Working Paper, 05/238.

AMITI, M.; and WEI, S.J. (2009). "Services Offshoring and Productivity: Evidence from the US". The World Economy, 32(2), pp. 203-220.

BERNHARD, M.; and RYCX, F. (2012). "Does offshoring of material and business services affect employment? Evidence from a small open economy". Applied Economics, 44, pp. 229-251.

BLINDER, A.S. (2006). "Offshoring: The Next Industrial Revolution?". Foreign Affairs, 82, pp. 113-127.

BHAGWATI, J.; PANAGARIYA, A. and SRINIVASAN, T. (2004). "The Muddles over Outsourcing". Journal of Economic Perspectives, 18(4), pp 93-114.

CADARSO, M.A.; LÓPEZ, L.A. and TOBARRA, M.A. (2007). "Especialización 
vertical, outsourcing e inversión directa en la industria española". Revista de Economía Mundial, Vol 16., pp. 27-55.

CADARSO, M.; GÓMEZ, N.; LÓPEZ, L.A. and TOBARRA, M.A. (2008). "The EU enlargement and the impact of outsourcing on industrial employment in Spain, 1993-03". Structural Change and Economic Dynamics, 19, pp. 95108.

CADARSO, M. A.; GÓMEZ, N.; LÓPEZ, L.A. and TOBARRA, M.A. (2012). "Offshoring components and their effect on employment: firms deciding about how and where". Applied Economics, 44, pp. 1009-1020.

CAMACHO, J.A., and RODRÍGUEZ, M. (2008). "Offshoring y Contenido en Servicios del Comercio Internacional en Europa. Un Análisis a través de las Tablas Input-Output". Información Comercial Española, 844, pp. 29-37.

CAMPA, J., and GOLBERG, L.S. (1997). "The evolving external orientation of manufacturing industries: Evidence from four countries". National Bureau of Economic Research, Working Paper, 5919.

CANALS, C. (2006). "Offshoring y Deslocalización: Nuevas Tendencias de la Economía Internacional”, Documentos de Economía La Caixa, 3.

CASTELLANI, D.; BENEDICTIS, L. and HORGOS, D. (2010). Import penetration vs. Outsourcing: What really drives the offshoring indices? Centro di Studi Luca d'Angliano, Milano.

CONTRACTOR, F. J.; KUMAR, V.; KUNDU, S.K. and PEDERSEN, T. (2010). "Reconceptualizing the firm in a world of outsourcing and offshoring: The organizational and geographical relocation of high-value company functions". Journal of Management Studies, 47, pp. 1417-1433.

DE BACKER, K., and YAMANO, N. (2007). "The measurement of globalisation using input-output tables". OCDE Science, Technology and Industry Working Papers, 2007/8 OCDE Publishing.

DESAI, M.A.; FOLEY, C.F. and HINES J.R (2005). "Foreign Direct Investment and Domestic Economy Activity". NBER Working Paper Series, 11717.

DÍAZ MORA, C.; GANDOY, R (2005). "Outsourcing en la industria manufacturera española: Nuevas estrategias para el nuevo siglo", Economía Industrial, 358, pp. 65-78.

DÍAZ MORA, C.; GANDOY, R. and GONZÁLEZ, B. (2007). "La Fragmentación Internacional en las Manufacturas Españolas". Papeles de Economía Española, 112, pp. 74-88.

DÍAZ MORA, C.; GANDOY, R. (2008). "Outsourcing en las industrias tradicionales: Determinantes de la estrategia", Revista de Estudios Empresariales. Segunda época, 1, pp. 41-64.

EGGER, H. and EGGER, P. (2001). "International outsourcing and the productivity of low-skilled labour in the EU”. WIFO Working Paper, 152.

EKHOLM, K. and HAKKALA, K. (2005). "The effect of offshoring on labor demand: Evidence from Sweden". IUI, The Research Institute of Industrial Economics Working Paper, 654. 
FARIÑAS, J.C. and MARTíN, A. (2009). "Innovaciones Organizativas y Productividad: El caso del Outsourcing Internacional". Investigaciones Regionales, Vol. Monográfico, pp. 251-275.

FEENSTRA, R.C., and Hanson, G.H. (1996). "Globalization, Outsourcing and wage inequality. American Economic Review, 86, pp. 31-50.

FEENSTRA, R. C., and Hanson, G.H. (1999). The impact of outsourcing and high-technology capital on wages: Estimates for the United States, 19791990". Quarterly Journal of Economics, 114, pp. 907-940.

GANDOY, R., and DÍAZ MORA, C. (2007). "El Offshoring en la industria española: Una revisión de la evidencia empírica". Información Comercial Española, 837, pp. 195-210.

GEISHECKER, I., and GÖRG, H. (2005). "Do unskilled workers always lose from fragmentation?" North American Journal of Economics and Finance, 16, pp. 81-92.

GÓMEZ, N.; LÓPEZ, L.A. and TABARRA M.A. (2006). "Pautas de Deslocalización de la Industria Española en el Entorno Europeo (1995-2000)". Boletín Económico de ICE, 2884, pp. 25-41.

GÖRG, H., HANLEY, A., and STROBL E. (2008). "Productivity effects of international outsourcing: Evidence from Plant-level Data". Canadian Journal of Economics, 41(2), pp. 670-88.

GROSSMAN, G.M. and ROSSI-HANSBERG E. (2006). "The Rise of Offshoring: It's Not Wine for Cloth Anymore". Symposium New Economic Geography: Effects and Policy Implications.

HIJZEN, A.; PISU, M.; UPWARD, R. and WRIGHT, P. (2007). "Employment, Job Turnover and Trade in Producer Services: Firm-Level Evidence". GEP Research Paper, 27, University of Nottingham.

LÓPEZ SANTIAGO, L.A., LÓPEZ DE LA NIETA, J. and ZAFRILLA, J.E. (2011). "Fragmentación, offshoring y vertebración de la economía española". Información Comercial Española, 859, pp. 141-161.

MANN, C.L. (2003). "Globalization of IT services and white collar jobs: the next wave of productivity growth". International Economics Policy Briefs, PB0311.

METTERS, R. (2007). "A Typology of Offshoring and Outsourcing in Electronically Transmitted Services". Journal of Operations Management, 26, pp. 198-211.

MERINO, F. y RODRÍGUEZ, D. (2007). "Service outsourcing by manufacturing firms: Theory and application". Industrial and Corporate Change, 16, pp. 1147-1173.

MINONDO, A., and RUBERT, G. (2001). "La Evolución del Outsourcing en el Sector Manufacturero". Boletín Económico de ICE, 2709, pp. 11-19.

MUÑOZ, M. (2007a). "La deslocalización de los servicios: ¿Mito o realidad?". Revista de Economía Mundial, 16, pp. 57-78. 
MUÑOZ, M. (2007b). "Are Foreign Firms Delocalising Services from Spain?". The Service Industries Journal, 27, 305-320.

MUÑOZ, M. (2008). "Offshoring en los Servicios. Evidencia para la Economía Española”. Boletín Económico ICE, 2932, pp. 29- 41.

MYRO, R., and FERNÁNDEZ-OTHEO, C.M. (2008): "Deslocalización de Empresas e Inversión Extranjera Directa en la Industria Española". Papeles de Economía Española, 116, pp. 184-202.

MYRO, R., and L. LABRADOR, L. (2008). "Deslocalización: Concepto, Formas y Efectos". Principios: Estudios de Economía Política, Vol. 10, 97-107.

OLSEN, K.B. (2006). "Productivity Impacts of Offshoring and Outsourcing: A review". OECD Science, Technology and Industry, Working Papers, 2006/1, OECD Publishing.

RAA, T., and WOLFF, E. (2001). "Outsourcing of Services and the Productivity Recovery in U.S. Manufacturing in the 1980s and 1990s". Journal of Productivity Analysis, Vol. 16; 149-165.

RICART, J.E., and AGNESE, P. (2006): El Offshoring en España. Causas y Consecuencias de la deslocalización de servicios. IESE, Universidad de $\mathrm{Na}$ varra.

RICART, J.E., and ROSATTI, S. (2009). El Offshoring en España. Evolución y Perspectivas de la Deslocalización de Servicios en 2008. Fundación BBVA e IESE, Universidad de Navarra.

WINKLER, D. (2010). "Services offshoring and its impact on productivity and employment: Evidence from Germany, 1995-2006". The world Economy (doi: 10.1111/j.1467-9701.2010.01269.x). 